\title{
Fructose and mannose metabolism in Aeromonas hydrophila: identification of transport systems and catabolic pathways
}

\author{
Marie R. B. Binet, ${ }^{1}$ Marie-Noelle Rager $^{2}$ and Odile M. M. Bouvet ${ }^{1}$ \\ Author for correspondence: Odile M. M. Bouvet. Tel: +3314061 36 73. Fax: +3314568 8837. \\ e-mail: obouvet@pasteur.fr
}

1 Unité des Entérobactéries Institut National de la Santé et de la Recherche U389, Institut Pasteur, 75724 Paris cedex 15, France

2 Service de Résonance Magnétique Nucléaire, URA 403, Ecole Nationale Supérieure de Chimie de Paris, 75231 Paris cedex 05, France

\begin{abstract}
Aeromonas hydrophila was examined for fructose and mannose transport systems. A. hydrophila was shown to possess a phosphoenolpyruvate (PEP) : fructose phosphotransferase system (fructose-PTS) and a mannosespecific PTS, both induced by fructose and mannose. The mannose-PTS of $A$. hydrophila exhibited cross-reactivity with Escherichia coli mannose-PTS proteins. The fructose-PTS proteins exhibited cross-reactivities with $E$. coli and Xanthomonas campestris fructose-PTS proteins. In A. hydrophila grown on mannose as well as on fructose, the phosphorylated derivative accumulated from fructose was fructose 1-phosphate. Identification of fructose 1-phosphate was confirmed by ${ }^{13} \mathrm{C}$-NMR spectroscopy. 1-Phosphofructokinase (1-PFK), which converts the product of the PTS reaction to fructose 1,6-diphosphate, was present in A. hydrophila grown with fructose but not on mannose. An inducible phosphofructomutase (PFM) activity, an unusual enzyme converting fructose 1-phosphate to fructose 6-phosphate, was detected in extracts induced by mannose or fructose. These results suggest that in cells grown on fructose, fructose 1-phosphate could be converted to fructose 1,6-diphosphate either directly by the 1-PFK activity or via fructose 6-phosphate by the PFM and 6-phosphofructokinase activities. In cells grown on mannose, the degradation of fructose 1-phosphate via PFM and the Embden-Meyerhof pathway appeared to be a unique route.
\end{abstract}

Keywords: phosphotransferase system, Aeromonas bydrophila, fructose, mannose, catabolic pathways

\section{INTRODUCTION}

The genus Aeromonas used to belong to the family Vibrionaceae (Farmer, 1992). Colwell et al. (1986) classified the genus Aeromonas in a new family, the Aeromonadaceae. The phylogenetic position of the Aeromonadaceae is in the gamma group of Proteobacteria with other families such as Enterobacteriaceae, Vibrionaceae and Pasteurellaceae and genera Pseudomonas and Xanthomonas (Woese, 1987).

Aeromonas hydrophila causes disease in fish, frogs and several other animals (Farmer et al., 1992). It is now recognized as an opportunistic pathogen of humans (Thornley et al., 1997). To understand the ability of $A$.

Abbreviations: KDPG, 2-keto-3-deoxy-6-phosphogluconate; PEP, phosphoenolpyruvate; 1-PFK, 1-phosphofructokinase; 6-PFK, 6-phosphofructokinase; PFM, phosphofructomutase; PTS, phosphotransferase system. bydrophila to grow and survive in its environment, it is essential to know the mechanisms by which nutrients are taken up and metabolized.

In many Gram-negative bacteria, the phosphoenolpyruvate (PEP)-dependent phosphotransferase system (PTS) mediates active transport and concomitant phosphorylation of sugars and hexitols (Postma \& Lengeler, 1985; Postma et al., 1993). It consists of two general energy-coupling proteins (enzyme I and $\mathrm{HPr}$ ) and a number of sugar-specific transmembrane permeases (enzymes II). In Escherichia coli, two enzyme II systems mediating glucose transport have been described (Curtis \& Epstein, 1975). They can be distinguished by their different sugar specificities (Rephaeli \& Saier, 1980; Scholte \& Postma, 1981). The II Glc system (glucosePTS), of narrow specificity for glucose and $\alpha$-methylglucoside, comprises a membrane-bound permease (enzyme IICB ${ }^{\mathrm{Glc}}$ ) and a soluble protein (enzyme IIA ${ }^{\mathrm{Glc}}$ ). 
The second system (mannose-PTS), of broader specificity (including mannose, glucose, 2-deoxyglucose, $\mathrm{N}$-acetylglucosamine, glucosamine and fructose with decreasing affinity in that order), comprises a IIAB ${ }^{\text {Man }}$ protein (a hydrophilic protein) (Stolz et al., 1993) which is phosphorylated during the phosphate transfer whereas IIC $^{\text {Man }}$ and IID ${ }^{\text {Man }}$ (integral membrane proteins) are not (Erni \& Zanolari, 1985; Williams et al., 1986). In the family Vibrionaceae, 15 species studied contained a PTS analogous to the glucose-PTS in the Enterobacteriaceae (Meadow et al., 1987). Four components (enzyme I, $\mathrm{HPr}$, enzyme IIA ${ }^{\mathrm{GlC}}$ and enzyme $\mathrm{IICB}^{\mathrm{Glc}}$ ) of the glucosePTS were separated and purified in Vibrio parahaemolyticus (Kubota et al., 1979). Glucose and mannose are also PTS sugars in Vibrio furnissii (Bouma \& Roseman, 1996a, b).

For PTS-mediated fructose transport in E. coli (Hanson \& Anderson, 1968; Saier et al., 1976), a protein called FPr (fructose-specific HPr) was identified which combines the functions of the IIA ${ }^{\text {Fru }}$ domain and of an HPrlike protein (Geerse et al., 1989). In this case, it is FPr rather than HPr that is phosphorylated by enzyme I. At a low concentration (less than $2 \mathrm{mM}$ ), fructose enters $E$. coli via the membrane-bound permease (enzyme IIBC $^{\text {Fru }}$ ) and appears inside the cell as fructose 1phosphate; at higher concentrations, it can also enter via the membrane-bound permease (enzyme IICD ${ }^{\text {Man }}$ ) and appears inside the cell as fructose 6-phosphate. In Rhodobacter capsulatus (Saier et al., 1971; Wu et al., 1990) and Xanthomonas campestris (De Crécy-Lagard et al., 1991a, b, 1995), a high-molecular-mass soluble protein called MTP (multiphosphoryl transfer protein) was identified which combines the functions of the enzyme IIA $^{\text {Fru }}$, HPr and enzyme I domains. During the process, fructose is phosphorylated to fructose 1phosphate, which is further metabolized to fructose 1,6diphosphate by 1-phosphofructokinase (1-PFK). In the present study, we report the presence of a mannosespecific PTS and a fructose-specific PTS both induced by fructose and mannose, and we propose a new fructose catabolic pathway in A. bydrophila grown with mannose.

\section{METHODS}

Bacterial strains and growth conditions. Strains used were: Aeromonas bydrophila CIP $7614^{\mathrm{T}}$, obtained from the Collection de l'Institut Pasteur; Xanthomonas campestris pathovar campestris NRRLB 1459 (Jeanes et al., 1961); and Escherichia coli TP2811, $\mathrm{F}^{-}$xyl argH1 ilvA aroB $\Delta$ lacX74 $\Delta$ (ptsH ptsI crr) $\mathrm{Km}^{\mathrm{r}}$ (Lévy et al., 1990).

For PTS assays and the preparation of crude extract and cytoplasmic and membrane fractions, A. bydrophila was grown in minimal medium (Tanaka et al., 1967) supplemented with $0.03 \%(\mathrm{w} / \mathrm{v})$ Casamino acids and $0.2 \%(\mathrm{w} / \mathrm{v})$ fructose, mannose or Casamino acids at $30^{\circ} \mathrm{C}$ with shaking for $12-15 \mathrm{~h}$. $X$. campestris and E. coli TP2811 were grown in Luria-Bertani broth (Maniatis et al., 1982) containing $0 \cdot 2 \%(\mathrm{w} / \mathrm{v})$ fructose or mannose at $30^{\circ} \mathrm{C}$ with shaking for $12-15 \mathrm{~h}$. Cells were harvested by centrifugation in the late exponential phase of growth.
Preparation of membrane and cytoplasmic fractions. Cells were washed three times with $20 \mathrm{mM}$ Tris $/ \mathrm{HCl}$ buffer (pH 7.5) containing $1 \mathrm{mM}$ DTT and $1 \mathrm{mM}$ EDTA and frozen at $-20^{\circ} \mathrm{C}$. Cells were resuspended in the same buffer to approximately $0 \cdot 2 \mathrm{~g}$ (wet $\mathrm{wt}$ ) $\mathrm{ml}^{-1}$ and were sonicated (Branson sonifier 450 tip 3) three times for $1 \mathrm{~min}$ in an ethanol/ice bath with $1 \mathrm{~min}$ allowed for cooling between sonications. The homogenate was centrifuged for $15 \mathrm{~min}$ at $5000 \mathrm{~g}$ to remove intact cells and cell debris. The resulting cellfree extract (crude extract) was centrifuged at $200000 \mathrm{~g}$ for $3 \mathrm{~h}$ at $4{ }^{\circ} \mathrm{C}$. The clear supernatant was removed and the membrane pellet was washed with $20 \mathrm{mM}$ Tris/ $\mathrm{HCl}$ buffer ( $\mathrm{pH} 7.5$ ) containing $1 \mathrm{mM}$ DTT and $1 \mathrm{mM}$ EDTA, and resuspended in the same buffer. Cytoplasmic fractions were concentrated three- to fivefold on Centricon 3 (Amicon). The membrane pellet, the cytoplasmic fraction and the crude extract were stored at $4{ }^{\circ} \mathrm{C}$.

Assays for PEP:sugar PTS activity and ATP:sugar phosphorylation activity in toluene-treated cells. Cells were washed three times in M63 minimal medium (Miller, 1972) and then suspended in M63 minimal medium to $0 \cdot 15 \mathrm{~g}$ wet weight $\mathrm{ml}^{-1}$. Phosphorylation of $\left[{ }^{14} \mathrm{C}\right]$ fructose or $\left[{ }^{14} \mathrm{C}\right]$ mannose $\left(250 \mu \mathrm{M} ; 290 \mathrm{mCi} \mathrm{mmol}^{-1}, 10.7 \mathrm{GBq} \mathrm{mol}^{-1}\right)$ was assayed in cells which were treated with toluene. The optimal amount of toluene was determined previously using $0.5-10 \mu \mathrm{l}$ toluene. A $1 \mathrm{ml}$ aliquot of bacterial suspension was mixed with $2 \mu \mathrm{l}$ toluene and incubated for $25 \mathrm{~min}$ at $30^{\circ} \mathrm{C}$. The reaction was monitored as described by Bouvet $\&$ Grimont (1987) at $30^{\circ} \mathrm{C}$. PEP or ATP was used as phosphate donor at a final concentration of $5 \mathrm{mM}$ or $10 \mathrm{mM}$ (respectively) and the reaction was stopped at different times by flash-freezing. The results are presented as the amount $(\mathrm{nmol}) \mathrm{min}^{-1}$ (mg protein) $)^{-1}$ of labelled fructose or mannose converted to phosphorylated $\left[{ }^{14} \mathrm{C}\right]$ fructose or $\left[{ }^{14} \mathrm{C}\right]$ mannose in the presence or the absence of PEP or ATP and represent a mean of at least three determinations. For competition assays, the substrate specificity of membrane-bound permeases was determined by measuring the extent to which unlabelled sugars (fructose, mannose, 2-deoxyglucose and $N$-acetylglucosamine at $10 \mathrm{mM}$ ) reduced the rate of PEP-dependent phosphorylation of $\left[{ }^{14} \mathrm{C}\right]$ fructose or $\left[{ }^{14} \mathrm{C}\right]$ mannose at $500 \mu \mathrm{M}$ when added simultaneously to the reaction mixture. The results are expressed as percentage inhibition of the $\left[{ }^{14} \mathrm{C}\right]$ fructose or $\left[{ }^{14} \mathrm{C}\right]$ mannose phosphorylation.

Assays for PEP:sugar PTS activity in cell extracts. PTS activities were assayed by measuring the PEP-dependent phosphorylation of ${ }^{14} \mathrm{C}$-labelled sugars. The following reaction mixture was incubated at $30^{\circ} \mathrm{C}: 10 \mathrm{mM} \mathrm{MgCl}, 1 \mathrm{mM}$ DTT, $12.5 \mathrm{mM} \mathrm{KF}, 140 \mu \mathrm{l}$ crude extract, cytoplasmic fraction or membranes in $50 \mathrm{mM}$ sodium phosphate buffer $(\mathrm{pH}$ 7) with or without $10 \mathrm{mM}$ PEP. The reaction was initiated by adding $\left[{ }^{14} \mathrm{C}\right]$ fructose or $\left[{ }^{14} \mathrm{C}\right]$ mannose to a final concentration of $250 \mu \mathrm{M}\left(290 \mathrm{mCi} \mathrm{mmol}^{-1}, 10 \cdot 7 \mathrm{GBq} \mathrm{mmol}^{-1}\right)$ or 2-deoxyglucose to a final concentration of $400 \mu \mathrm{M}\left(10.7 \mathrm{GBq} \mathrm{mmol}^{-1}\right)$. The reaction was stopped at different times by flash-freezing and phosphorylated sugars were separated from sugar as previously described (Bouvet \& Grimont, 1987). The results represent a mean of at least three determinations and were linear over $5 \mathrm{~min}$.

Determination of kinetic constants of mannose- and fructosePTS by uptakes of $\left[{ }^{14} \mathrm{C}\right]$ fructose and $\left[{ }^{14} \mathrm{C}\right]$ mannose in intact cells. To determine kinetic constants $\left(K_{m}\right.$ and $\left.V_{\max }\right)$, the cell density was adjusted to $\operatorname{OD}_{600} 0 \cdot 15$ and concentrations of $\left[{ }^{14} \mathrm{C}\right]$ fructose and $\left[{ }^{14} \mathrm{C}\right]$ mannose varying from $0 \cdot 1$ to $5 \mu \mathrm{M}$ were added. The reaction mixture was incubated at $30^{\circ} \mathrm{C}$ and 
aliquots were taken at different times (each $10 \mathrm{~s}$ for $2 \mathrm{~min}$ ), deposited on GF/C filters (Whatman; $2.5 \mathrm{~cm}$ diameter), then washed with $M 63$ medium to remove unincorporated $\left[{ }^{14} \mathrm{C}\right]$ fructose and $\left[{ }^{14} \mathrm{C}\right]$ mannose. Each filter was dried and the radioactivity was measured in a scintillation counter. Results obtained were calculated as nmol ${ }^{14} \mathrm{C}$-labelled sugars transported $\min ^{-1}$ (mg protein) ${ }^{-1}$. Rates were linear for $20-30 \mathrm{~s}$ and kinetic constants were determined by Lineweaver-Burk plots.

Identification of fructose-PTS products by TLC and ${ }^{43} \mathrm{C}$-NMR spectroscopy. PEP: sugar phosphorylation assays in toluenetreated cells of $A$. hydrophila induced by fructose or by mannose were performed as described above except that reactions were started by adding $500 \mu \mathrm{M}\left[{ }^{14} \mathrm{C}\right]$ fructose $\left(290 \mathrm{mCi} \mathrm{mmol}^{-1}, 10.7 \mathrm{GBq} \mathrm{mmol}^{-1}\right)$ or $\left[1{ }^{13} \mathrm{C}\right]$ fructose (EURISO-top) in the presence of PEP (final concentration of $5 \mathrm{mM}$ ) or ATP (final concentration of $10 \mathrm{mM}$ ). The reaction was stopped after $5 \mathrm{~min}$ at $30^{\circ} \mathrm{C}$ by flash-freezing. Aliquots $\langle 10 \mu \mathrm{l})$ were deposited on thin layer plates of MN300 cellulose (Merck) with reference compounds in the same way. Chromatography was performed as described by Ferenci \& Kornberg (1973). Chromatograms were developed twice in ammonium acetate $(\mathrm{pH} 5), 95 \%(\mathrm{v} / \mathrm{v})$ ethanol, $0 \cdot 1 \mathrm{M}$ disodium EDTA $\left(30: 70: 1\right.$, by vol.) at $30{ }^{\circ} \mathrm{C}$. The positions of free $\left[{ }^{14} \mathrm{C}\right]$ fructose and the labelled reaction products were located by placing the plates in contact with Amersham Hyperfilm-MP. The position of reference compounds (fructose 1-phosphate, fructose 6phosphate, fructose 1,6-diphosphate) on the chromatograms was revealed using a spray composed of $4 \%(\mathrm{w} / \mathrm{v})$ ammonium molybdate, butanol and $3 \mathrm{M}$ sulfuric acid (10:25:10, by vol.) (Wawszkiewicz, 1961) and was used to identify labelled reaction products. The identification of products accumulated in toluene-treated cells grown on fructose and on mannose was confirmed by a ${ }^{13} \mathrm{C}-\mathrm{NMR}$ experiment. The area containing the $1-{ }^{13} \mathrm{C}$-labelled reaction product was located by autoradiography. After that, the zone was scraped off and the sorbent was collected. The $1{ }^{13} \mathrm{C}$-labelled reaction product was extracted with distilled water and analysed by ${ }^{13} \mathrm{C}-\mathrm{NMR}$ spectroscopy.

NMR spectroscopy. All NMR data were recorded at $303 \mathrm{~K}$ on a Bruker AM250 spectrometer using a $10 \mathrm{~mm}$ broadband probe. The sample was introduced in an $8 \mathrm{~mm}$ NMR tube, itself inserted in a $10 \mathrm{~mm}$ NMR tube containing ${ }^{2} \mathrm{H}_{2} \mathrm{O}$.

${ }^{13} \mathrm{C}-\mathrm{NMR}$ spectra were acquired with composite pulse decoupling. The instrumental parameters were: operating frequency, $62.9 \mathrm{MHz}$; spectral width, $15625 \mathrm{~Hz}$; memory size, $32 \mathrm{~K}$; recycling time, $2.05 \mathrm{~s}$; number of transients, 108000 ; and pulse angle, $40^{\circ}$. Exponential filtering of $3 \mathrm{~Hz}$ was applied prior to Fourier transformation. Chemical shifts were referred to tetramethylsilane through the use of the $\alpha-\mathrm{C} 1$ glucose resonance at 93.0 p.p.m. as an internal reference. Metabolite peaks were identified from their chemical shifts. The assignments were confirmed by adding authentic samples of each metabolite to the medium.

${ }^{31}$ P-NMR spectra were acquired with composite pulse decoupling. The instrumental parameters were: operating frequency, $101.2 \mathrm{MHz}$; spectral width, $4065 \mathrm{~Hz}$; memory size, $16 \mathrm{~K}$; recycling time, $2.015 \mathrm{~s}$; number of transients, 280 ; and pulse angle, $45^{\circ}$. Exponential filtering of $1 \mathrm{~Hz}$ was applied prior to Fourier transformation. Chemical shifts were given relative to external triethyl phosphate $(0$ p.p.m.), which was added to ${ }^{2} \mathrm{H}_{2} \mathrm{O}$. Metabolites were identified as described before.

Preparation of cell-free extracts for enzyme assays. Bacteria were harvested in the late exponential growth phase, washed three times in M63 minimal medium and resuspended to approximately $0.15 \mathrm{~g}$ (wet wt) $\mathrm{ml}^{-1}$ in $50 \mathrm{mM}$ Tris buffer (pH 7.5) with $5 \mathrm{mM} \mathrm{MgCl}, 2.5 \mathrm{mM}$ DTT, $12.5 \mathrm{mM} \mathrm{KF}$ and $1 \% \mathrm{KCl}$.

This bacterial suspension was added to glass beads $(0 \cdot 10$ $0.11 \mathrm{~mm}$ diameter) and the mixture was vigorously shaken five times for $30 \mathrm{~s}$ at $4{ }^{\circ} \mathrm{C}$ (Bouvet et al., 1994). After centrifugation $(1 \mathrm{~h}$ at $12000 \mathrm{~g})$, the supernatant was assayed for enzyme activity. Supernatants were stored at $-20^{\circ} \mathrm{C}$.

Enzyme assays. All assays were performed at room temperature and measured by spectrophotometric determination (at $340 \mathrm{~nm}$ ) of the rate of NADH oxidation or the rate of NAD/NADP reduction. Specific activities were expressed as nmol substrate consumed $\mathrm{min}^{-1}$ (mg protein) ${ }^{-1}$ and represented means of at least three determinations. Activities of the following enzymes were assayed as described in previous publications: 6-phosphofructokinase (6-PFK) and 1-PFK (Baumann \& Baumann, 1975), 6-phosphogluconate dehydratase and 2-keto-3-deoxy-6-phosphogluconate (KDPG) aldolase (Lessie \& Neidhart, 1967), phosphofructomutase (PFM), phosphoglucose isomerase, fructose-1,6-bisphosphatase and fructose-1,6-bisphosphate aldolase (Conrad \& Schlegel, 1977), and glucose-6-phosphate dehydrogenase and 6-phosphogluconate dehydrogenase (Conrad \& Schlegel, 1977).

Glucokinases and fructokinases were determined at $30^{\circ} \mathrm{C}$ by a radioactive method (Postma \& Stock, 1980) with or without $6 \mathrm{mM}$ ATP. Sugar phosphates were separated from unphosphorylated sugars by ion exchange chromatography (DE81; Whatman). $\left[{ }^{14} \mathrm{C}\right]$ Glucose and $\left[{ }^{14} \mathrm{C}\right]$ fructose were used at a final concentration of $10 \mathrm{mM}$ and $1 \mathrm{mM}$, respectively. To study substrate specificity, different substrates were added to the reaction mixture at final concentrations five- to tenfold higher than the radioactive substrate. For glucokinase activity, glucose, mannose and fructose $(50 \mathrm{mM})$ were used. For fructokinase activities, glucose, fructose, mannose, fructose 1phosphate, fructose 6-phosphate and fructose 1,6-diphosphate (10 $\mathrm{mM})$ were used. Specific activities were expressed as nmol sugar utilized $\mathrm{min}^{-1}$ (mg protein $)^{-1}$ and represented means of at least three determinations.

Protein assay. Protein concentration was determined by the method of Bradford (1976) using bovine serum albumin as standard.

\section{RESULTS}

\section{Sugar phosphorylation in toluene-treated cells and extracts}

To identify PTS activities towards fructose and mannose in A. bydrophila, PEP-dependent phosphorylation experiments were conducted both in cell extracts and in toluene-treated cells (Tables 1 and 2). In toluene-treated cells (Table 1), A. bydrophila exhibited PEP-dependent phosphorylation of $\left[{ }^{14} \mathrm{C}\right]$ fructose and $\left[{ }^{14} \mathrm{C}\right]$ mannose (and its analogue 2-deoxy $\left[{ }^{14} \mathrm{C}\right]$ glucose). Fructose-PTS activity was inducible by addition of fructose or mannose in the culture (Table 1). However, the mannose-PTS activity was induced to a low level during growth in the presence of fructose. When the same experiment was done using ATP instead of PEP, fructose was phosphorylated only in fructose-grown cells, mannose was weakly phosphorylated and 2-deoxyglucose was never phosphorylated by ATP (data not shown). 
Table 1. PEP-PTS activity for different ${ }^{14} \mathrm{C}$-labelled sugars in toluene-treated cells of $A$. hydrophila

\begin{tabular}{|llc|}
\hline Inducer* & $\begin{array}{c}{ }^{14} \text { C-labelled } \\
\text { sugarf }\end{array}$ & $\begin{array}{c}\text { PEP-dependent } \\
\text { phosphorylation } \\
\text { activity } \neq\end{array}$ \\
\hline Casamino acids & Fructose & $0 \cdot 4(0 \cdot 4)$ \\
& Mannose & $0 \cdot 3(0 \cdot 2)$ \\
Fructose & Fructose & $10 \cdot 1(0 \cdot 8)$ \\
& Mannose & $1 \cdot 5(0 \cdot 7)$ \\
Mannose & 2-Deoxyglucose & $1 \cdot 0(0 \cdot 5)$ \\
& Mannose & $8 \cdot 6(1 \cdot 2)$ \\
& 2-Deoxyglucose & $1 \cdot 7(0 \cdot 4)$ \\
& Fructose & $9 \cdot 6(1 \cdot 5)$ \\
\hline
\end{tabular}

"Inducer substrates were used at $0.2 \%$ in the culture.

$+\left[{ }^{14} \mathrm{C}\right]$ Fructose and $\left[{ }^{14} \mathrm{C}\right]$ mannose were used at a final concentration of $250 \mu \mathrm{M} ; 2$-deoxy $\left[{ }^{14} \mathrm{C}\right]$ glucose was used at a final concentration of $400 \mu \mathrm{M}$.

$\ddagger$ PEP-dependent phosphorylation was monitored at $30^{\circ} \mathrm{C}$ as described in Methods. Results are expressed as nmol ${ }^{14} \mathrm{C}$-labelled sugar phosphorylated $\mathrm{min}^{-1} \mathrm{mg}^{-1}$. Values in parentheses correspond to the phosphorylation activity without PEP.

Whatever induction was used (fructose or mannose), extracts of A. hydrophila exhibited PEP-dependent phosphorylation of $\left[{ }^{14} \mathrm{C}\right]$ fructose and $\left[{ }^{14} \mathrm{C}\right]$ mannose (Table 2). Separation of extracts into soluble and membrane fractions resulted in loss of activities (data not shown), which were restored on recombining the two preparations (Table 2). These results suggested the presence of two PEP-dependent PTSs which transported and phosphorylated fructose and mannose. As for PTSs from other bacteria, these systems required the presence of cytoplasmic and membrane fractions. The detection of an ATP-dependent phosphorylation activity of fructose in fructose-grown cells suggested the presence of fructokinases in A. bydropbila.

When using heterologous complementation assays between membranes of $A$. hydrophila grown with mannose and the cytoplasmic fraction of A. hydrophila grown with fructose and inversely, a PEP-dependent phosphorylation of $\left[{ }^{14} \mathrm{C}\right]$ fructose and $\left[{ }^{14} \mathrm{C}\right]$ mannose (Table 2) was observed. These results demonstrated that each system is expressed in cells grown on fructose or mannose.

The specificity of membrane-bound permeases was determined by PEP-dependent phosphorylation of $\left[{ }^{14} \mathrm{C}\right]$ fructose and $\left[{ }^{14} \mathrm{C}\right]$ mannose $(500 \mu \mathrm{M})$ and by competition with different sugars added (fructose, glucose, mannose and $\mathrm{N}$-acetylglucosamine at $10 \mathrm{mM}$ ). In toluene-treated cells of $A$. hydrophila grown with fructose, the $\left[{ }^{14} \mathrm{C}\right]$ fructose phosphorylation was inhibited by fructose $(92 \%)$, while mannose, glucose and $\mathrm{N}$-acetylglucosamine did not significantly inhibit the activity (data not shown). In the same way, in toluene-treated cells of $A$. hydrophila grown with mannose, the $\left[{ }^{14} \mathrm{C}\right]$ mannose phosphorylation was strongly inhibited by mannose $(86 \%)$, while fructose, glucose and $\mathrm{N}$-acetylglucosamine

Table 2. Functional homology between $A$. hydrophila and $E$. coli mannose-PTSs and between $A$. hydrophila, $E$. coli and $X$. campestris fructose-PTSs by complementation assays

Aero $\mathrm{M}, A$. hydrophila induced by mannose during the culture; Aero F, A. hydrophila induced by fructose; E. coli TP2811 F or M, E. coli TP2811 mutant $\Delta(p t s H$ ptsI $\mathrm{crr}$ ) induced by fructose or by mannose during the culture; XC F, X. campestris induced by fructose. The amount of protein introduced in the reaction mixture was between 0.8 and $1.2 \mathrm{mg}$.

\begin{tabular}{|lclc|}
\hline $\begin{array}{l}\text { Cytoplasmic } \\
\text { fraction }\end{array}$ & $\begin{array}{c}\text { Membrane } \\
\text { fraction }\end{array}$ & $\begin{array}{c}{ }^{14} \text { C-labelled } \\
\text { sugar }\end{array}$ & $\begin{array}{c}\text { Phosphorylation } \\
\text { activity }\end{array}$ \\
\hline Aero M & Aero M & Mannose & $1 \cdot 14$ \\
Aero M & Aero F & Mannose & $0 \cdot 68$ \\
Aero F & Aero M & Mannose & $0 \cdot 75$ \\
Aero F & E. coli TP2811 M & 2-Deoxyglucose & $2 \cdot 97$ \\
Aero M & E. coli TP2811 M & 2-Deoxyglucose & $3 \cdot 74$ \\
Aero F & Aero F & Fructose & $0 \cdot 78$ \\
Aero F & Aero M & Fructose & $0 \cdot 81$ \\
Aero M & Aero F & Fructose & $0 \cdot 51$ \\
Aero F & E. coli TP2811 F & Fructose & $0 \cdot 85$ \\
Aero F & XC F & Fructose & $0 \cdot 13$ \\
Aero M & E. coli TP2811 F & Fructose & $1 \cdot 00$ \\
Aero M & XC F & Fructose & $0 \cdot 20$ \\
\hline
\end{tabular}

* $\left[{ }^{14} \mathrm{C}\right]$ Fructose and $\left[{ }^{14} \mathrm{C}\right]$ mannose were used at $250 \mu \mathrm{M}$ and 2 -deoxy $\left[{ }^{14} \mathrm{C}\right]$ glucose was used at $400 \mu \mathrm{M}$. † Results are expressed as nmol ${ }^{14} \mathrm{C}$-labelled sugars phosphorylated $\mathrm{min}^{-1} \mathrm{mg}^{-1}$. Activities in experiments without PEP were from 0.04 to $0.06 \mathrm{nmol} \mathrm{min}^{-1}$ (mg protein) ${ }^{-1}$. 


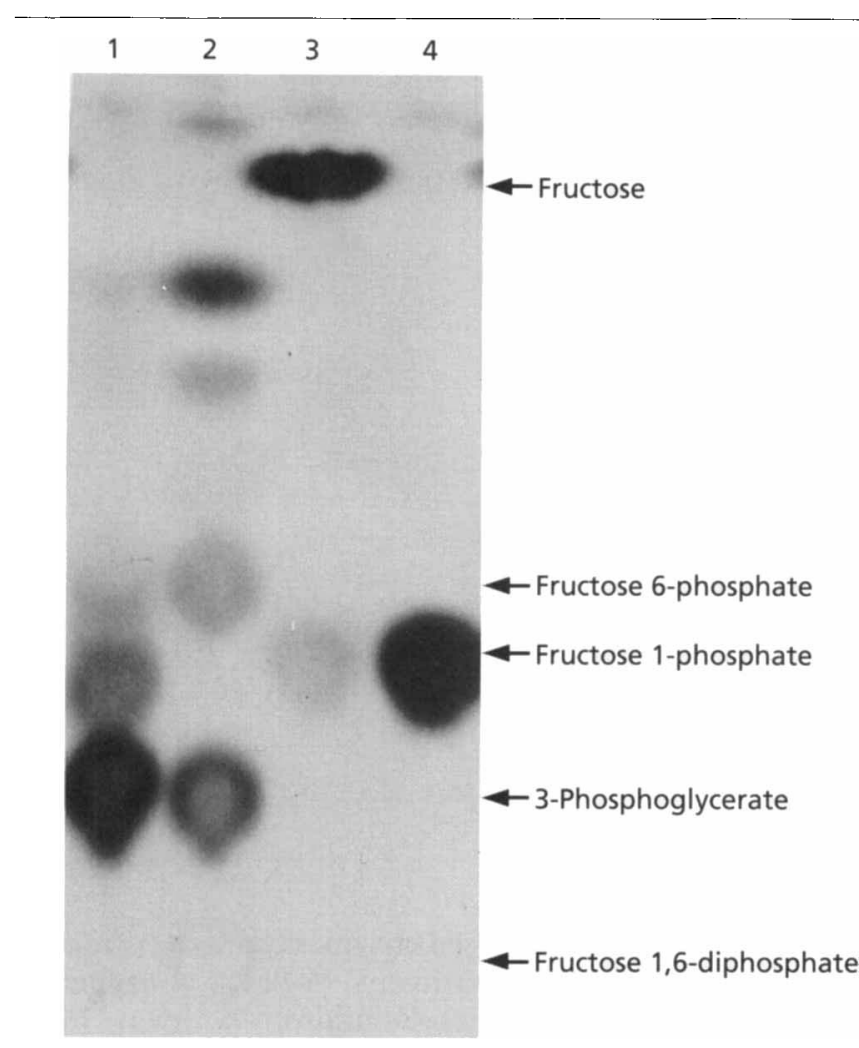

Fig. 1. Identification of $\left[{ }^{14} \mathrm{C}\right]$ fructose-PTS products by TLC. The figure shows products of fructose phosphorylation in $A$. hydrophila induced by fructose, in the presence of PEP (lane 1) or ATP (lane 2) for $5 \mathrm{~min}$, in A. hydrophila induced by fructose or by mannose without phosphate donor (lane 3), and in $A$. hydrophila induced by mannose in the presence of PEP (lane 4) for $5 \mathrm{~min}$.

did not significantly inhibit the activity $(<5 \%$, data not shown).

Kinetic constants were determined by uptake of $\left[{ }^{14} \mathrm{C}\right]$ fructose and $\left[{ }^{14} \mathrm{C}\right]$ mannose in intact cell assays. Apparent $K_{\mathrm{m}}$ values for fructose and mannose uptakes were $2.8 \mu \mathrm{M}$ and $2.3 \mu \mathrm{M}$, respectively, and the apparent $V_{\max }$ of fructose uptake was $60 \cdot 9 \mathrm{nmol} \mathrm{min}{ }^{-1}(\mathrm{mg}$ protein $)^{-1}$ and $26 \cdot 8 \mathrm{nmol} \mathrm{min}^{-1}(\mathrm{mg} \text { protein })^{-1}$ for mannose uptake.

\section{Identification of fructose-PTS products by TLC and ${ }^{13}$ C-NMR spectroscopy}

To determine the product of fructose phosphorylation in A. hydrophila grown with fructose or mannose, the phosphorylated derivatives of fructose accumulated in toluene-treated cells were chromatographed as described in Methods. As shown in Fig. 1, phosphorylated derivatives accumulated from fructose in the presence of PEP (lane 1) in A. hydrophila grown with fructose were products having the same $R_{F}$ values as fructose 1phosphate and 3-phosphoglycerate. In the presence of ATP (lane 2), accumulated phosphorylated derivatives were products having the same $R_{F}$ values as fructose 6phosphate and 3-phosphoglycerate. Other unidentified

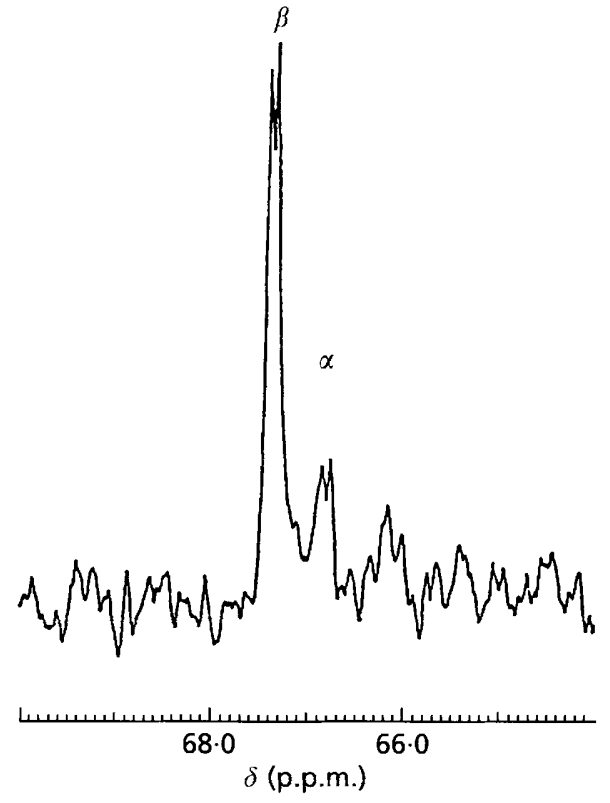

Fig. 2. Identification of fructose-PTS products accumulated in toluene-treated cells grown on mannose by ${ }^{13} \mathrm{C}-\mathrm{NMR}$ spectroscopy. The resonance peaks were assigned to $\beta$ - $(67.4$ and 67.3 p.p.m.) and $\alpha-(66.9$ and 66.8 p.p.m.) fructofuranose 1 phosphate.

products were visible. Only traces of fructose 1-phosphate were detectable without phosphate donor (lane 3). In $A$. hydrophila grown with mannose, the phosphorylated derivative accumulated from fructose, in the presence of PEP (lane 4), was fructose 1-phosphate too. 3-Phosphoglycerate was not detected. The identification of the fructose-PTS product and 3-phosphoglycerate accumulated in toluene-treated cells grown on fructose and mannose was confirmed by ${ }^{13} \mathrm{C}-\mathrm{NMR}$ spectroscopy (Fig. 2). The PEP-sugar phosphorylation assay was initiated by adding $\left[1-{ }^{13} \mathrm{C}\right]$ fructose and the phosphorylation derivative labelled at the $\mathrm{C} 1$ position was identified. The resonance peaks were assigned to $\alpha$ - and $\beta$-fructofuranose 1-phosphate.

The results suggested the presence of a PEP:fructosespecific PTS in A. hydrophila grown on fructose or mannose which produced fructose 1-phosphate and the presence of a PEP: mannose-specific PTS in A. hydrophila grown with fructose or mannose. The fact that in cells grown on mannose, the phosphorylated derivative accumulated from fructose in the presence of PEP was not fructose 6-phosphate confirms that fructose could not be transported and phosphorylated by mannosePTS.

\section{Interaction with other PTS systems}

The functional homology between the A. bydrophila fructose-PTS and mannose-PTS and PTSs from other bacteria was examined in heterologous sugar phosphorylation assays by using soluble and membrane fractions from different sources (Table 2). Membranes 
Table 3. Specific activities of some enzymes of carbohydrate metabolism in cell-free extracts of $A$. hydrophila

\begin{tabular}{|c|c|c|c|}
\hline \multirow[t]{2}{*}{ Enzyme } & \multicolumn{3}{|c|}{$\begin{array}{l}\text { Specific activity [nmol }(\mathrm{mg} \text { protein })^{-1} \\
\mathrm{~min}^{-1} \text { ] after growth in minimal } \\
\text { medium containing: }\end{array}$} \\
\hline & $\begin{array}{l}\text { Casamino } \\
\text { acids }\end{array}$ & Fructose & Mannose \\
\hline 6-PFK & $<20$ & 720 & 650 \\
\hline 1-PFK & $<30$ & 257 & $<30$ \\
\hline Phosphoglucose isomerase & 620 & 1579 & 1610 \\
\hline PFM & $<20$ & 47 & 60 \\
\hline Fructose-bisphosphate aldolase & $<30$ & 329 & 457 \\
\hline Fructose-bisphosphatase & $<20$ & 48 & 68 \\
\hline Glucose-6-phosphate dehydrogenase & $<10$ & $<10$ & $<10$ \\
\hline 6-Phosphogluconate dehydrogenase & $<10$ & $<10$ & $<10$ \\
\hline $\begin{array}{l}\text { 6-Phosphogluconate dehydratase and } \\
\text { KDPG aldolase }\end{array}$ & $<20$ & $<20$ & $<20$ \\
\hline
\end{tabular}

of E. coli TP2811 $\Delta$ (ptsH ptsI crr) grown with fructose or mannose or of $X$. campestris grown with fructose exhibited negligible activities of $\left[{ }^{14} \mathrm{C}\right]$ fructose and $\left[{ }^{14} \mathrm{C}\right]$ mannose phosphorylation (data not shown). The cytoplasmic fraction from $A$. bydrophila grown with fructose or mannose was capable of complementing membranes from E. coli TP2811 and X. campestris grown with fructose for phosphorylation of fructose (Table 2). However, values obtained with the $X$. campestris extract were very low (compared with other activities). This is probably due to the instability of $X$. campestris extracts. In the same way, the cytoplasmic fraction from $A$. bydrophila grown with fructose or mannose was capable of complementing membranes from E. coli TP2811 grown with mannose for phosphorylation of 2-deoxyglucose (Table 2).

The fructose-PTS in A. hydrophila grown with fructose or mannose exhibited cross-reactivity with E. coli and $X$. campestris cytoplasmic fructose-PTS proteins. The mannose-PTS in A. hydrophila grown with fructose and mannose exhibited cross-reactivity with $E$. coli cytoplasmic mannose-PTS proteins.

\section{Catabolic pathways of A. hydrophila}

An ATP-dependent phosphorylation of fructose, phosphorylating intracellular fructose to fructose 6-phosphate, was detected in $A$. bydrophila extracts. A. bydrophila exhibited fructokinase activity of $12.6 \mathrm{nmol}$ phosphorylated $\left[{ }^{14} \mathrm{C}\right]$ fructose $\min ^{-1}$ (mg protein $)^{-1}$ and was $80 \%$ inhibited by fructose 1-phosphate, $69 \%$ by fructose 6-phosphate, $48 \%$ by fructose 1,6-diphosphate, $14 \%$ by mannose and $10 \%$ by glucose. This fructokinase activity was inducible by fructose and not by mannose. The activities of enzymes involved in glucidic metabolism were measured spectrophotometrically in cell-free extracts (Table 3). A. hydrophila grown with fructose or mannose possessed enzymes characteristic of the Embden-Meyerhof pathway (6-PFK). Enzymes characteristic of the Entner-Doudoroff pathway (6phosphogluconate dehydratase and KDPG aldolase) and of the pentose phosphate pathway (glucose-6-phosphate dehydrogenase and 6-phosphogluconate dehydrogenase) were not detected in crude extracts of $A$. hydrophila. Phosphoglucose isomerase and fructose-1,6-bisphosphate aldolase were present in fructose-grown cells as in mannose-grown cells. In addition, an inducible PFM activity (Conrad \& Schlegel, 1977), an unusual enzyme converting fructose 1-phosphate to fructose 6-phosphate, was detected in extracts induced by fructose and mannose (Table 3).

The phosphorylation of fructose by the fructose-PTS of E. coli (Ferenci \& Kornberg, 1974), X. campestris (De Crécy-Lagard et al., 1991a) and Streptococcus salivarius (Bourassa \& Vadeboncoeur, 1992) gives rise to fructose 1-phosphate, which is further metabolized to fructose 1,6-diphosphate by 1-PFK. The extract of A. hydrophila grown with fructose had detectable 1-PFK activity. No activity of this enzyme was detected in extracts prepared from $A$. hydrophila grown with mannose (Table 3). This surprising result was confirmed by ${ }^{31} \mathrm{P}-\mathrm{NMR}$ spectroscopy by incubating cell-free extracts with fructose 1-phosphate and ATP (data not shown). In the extract of $A$. bydrophila grown with fructose, resonances corresponding to ADP, $\mathrm{P}_{\mathrm{i}}$ and fructose 1,6diphosphate appeared during time-courses indicating 1PFK activity. No activity could be detected in extracts of A. hydrophila grown with mannose.

\section{DISCUSSION}

The observations reported above demonstrate the presence of a fructose-specific PTS and a mannose-specific PTS which are both inducible by fructose and mannose. 
Grown on fructose
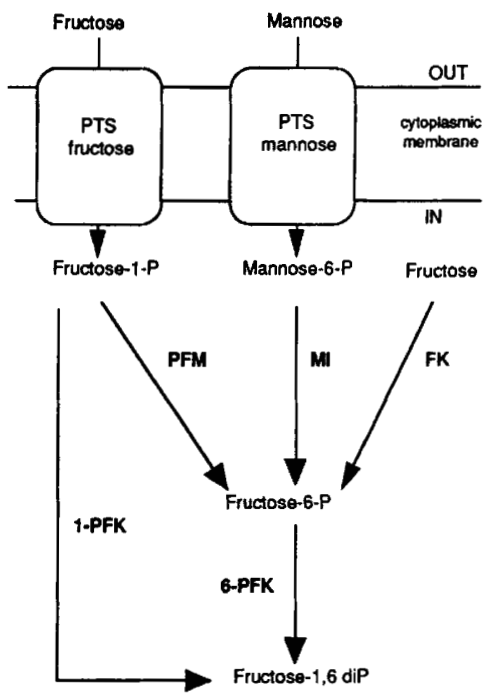

Grown on mannose
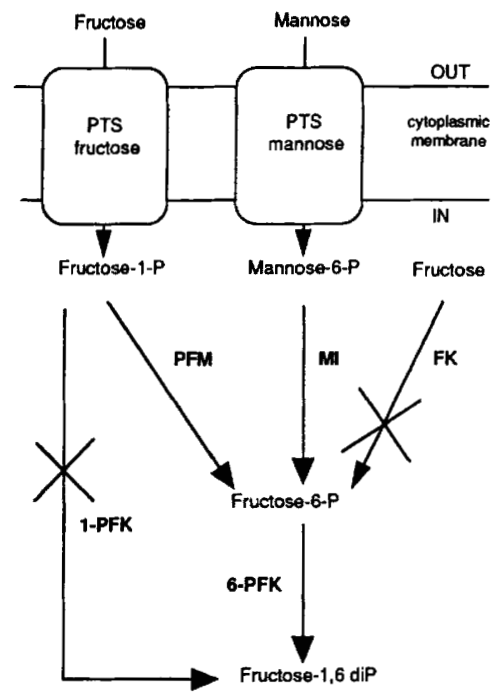

Fig. 3. Proposed pathways for transport and metabolism of fructose and mannose in $A$. hydrophila. FK, fructokinase; MI, mannose6-phosphate isomerase.
Each system requires both membrane and cytoplasmic fractions to be functional.

The mannose-PTS in $A$. hydrophila exhibited crossreactivity with $E$. coli mannose-PTS proteins. The tight specificity of the mannose-PTS discovered in A. bydrophila contrasts with the broad specificity of the mannosePTS of E. coli. Moreover, this system is present in $A$. bydrophila cells grown with mannose or fructose. Phosphorylated proteins with molecular masses similar to those of E. coli mannose-PTS proteins were visualized when incubated with [ $\left.{ }^{32} \mathrm{P}\right] \mathrm{PEP}$ (Mattoo \& Waygood, 1983; Waygood et al., 1984) (data not shown). Additional experiments are necessary to confirm identification of the labelled proteins.

In $E$. coli and other Gram-negative bacteria, enzyme IIA $^{\text {Gle }}$, a component of the PTS, regulates the adenylate cyclase activity (Lévy et al., 1990) and plays an important regulation role in catabolic repression and in inducer exclusion depending on its phosphorylation state. The A. hydrophila adenylate cyclase gene (Trotot et al., 1996) has been cloned and sequenced. The presence of a PTS system and of an adenylate cyclase in A. hydrophila could suggest a possible regulatory role of the PTS as in E. coli and other Gram-negative bacteria (Crasnier \& Danchin, 1990; Feucht \& Saier, 1980).

The transport and phosphorylation of fructose which yields fructose 1-phosphate and the substrate specificity restricted to fructose clearly demonstrates the presence of fructose-specific enzymes II. Phosphorylated proteins with molecular masses similar to those of $X$. campestris fructose-PTS proteins (enzyme IIBC $^{\text {Fru }}$ and a highmolecular-mass protein, MTP-like) were detected using $\left[{ }^{32} \mathrm{P}\right] \mathrm{PEP}-\mathrm{dependent}$ protein phosphorylation assays (data not shown). Further experiments are necessary to confirm identification of these labelled proteins. The fructose-PTS of $A$. hydrophila grown on fructose and mannose generates cytoplasmic fructose 1-phosphate.
This phosphate sugar is further phosphorylated to give fructose 1,6-diphosphate. In A. bydrophila grown with fructose, the presence of an inducible PEP-fructose-PTS and 1-PFK, together with a PFM activity and a 6-PFK activity, suggested that fructose 1 -phosphate was directly degraded to fructose 1,6-diphosphate or via fructose 6-phosphate (Fig. 3). In mannose-grown cells, 1 -PFK was not induced. Only the PFM and 6-PFK activities were present, suggesting that fructose 1phosphate was degraded via fructose 6-phosphate. In E. coli, genes encoding the enzymes of the fructose-PTS and 1-PFK form an operon (Geerse et al., 1989; JonesMortimer \& Kornberg, 1974). The arrangement of these genes is not known in $A$. hydrophila but our results indicated that the regulation of the genes encoding the fructose-PTS and 1-PFK was not coordinated. To our knowledge, uncoordinated regulation of the fructose genes has never been found in Gram-negative bacteria, only in Gram-positive bacteria (Bourassa \& Vadeboncoeur, 1992; Chassy \& Thompson, 1983; Leblanc et al., 1979).

A rare PFM activity was detected in extracts of cells induced by mannose and fructose. This prevents toxic accumulation of fructose 1-phosphate in the cells grown on mannose.

Durham \& Phibbs (1982) reported that both soluble and membrane fractions of the fructose-PTS from Pseudomonas aeruginosa do not cross-complement the respective systems in E. coli and vice versa. In this study, we observed that $A$. hydrophila fructose-PTS proteins exhibit cross-reactivities and functional homologies with E. coli and X. campestris fructose-PTS proteins.

\section{ACKNOWLEDGEMENTS}

We are grateful to $H$. de Reuse and V. de Crécy-Lagard for providing us with the pts mutant strain of E. coli and the $X$. campestris strain. M.R.B.B. is the recipient of a doctoral 
fellowship from the Ministère de l'Enseignement Supérieur et de la Recherche.

\section{REFERENCES}

Baumann, P. \& Baumann, L. (1975). Catabolism of D-fructose and D-ribose by Pseudomonas doudoroffii. I. Physiological studies and mutant analysis. Arch Microbiol 105, 225-240.

Bouma, C. L. \& Roseman, S. (1996a). Sugar transport by the marine chitinolytic bacterium Vibrio furnissii. Molecular cloning and analysis of the glucose and $\mathrm{N}$-acetylglucosamine permeases. $J$ Biol Chem 271, 33457-33467.

Bouma, C. L. \& Roseman, S. (1996b). Sugar transport by the marine chitinolytic bacterium Vibrio furnissii. Molecular cloning and analysis of the mannose/glucose permease. J Biol Chem 271, 33468-33475.

Bourassa, S. \& Vadeboncoeur, C. (1992). Expression of an inducible Enzyme II fructose and activation of a cryptic Enzyme II glucose in glucose-grown cells of spontaneous mutants of Streptococcus salivarius lacking the low-molecular-mass form of III ${ }^{\text {Man }}$, a component of the phosphoenolpyruvate: mannose phosphotransferase system. J Gen Microbiol 138, 769-777.

Bouvet, O. M. M. \& Grimont, P. A. D. (1987). Diversity of the phosphoenolpyruvate:glucose phosphotransferase system in the Enterobacteriaceae. Ann Inst Pasteur Microbiol 138, 3-13.

Bouvet, O. M. M., Lenormand, P., Carlier, J. P. \& Grimont, P. A. D. (1994). Phenotypic diversity of anaerobic glycerol dissimilation shown by seven enterobacterial species. Res Microbiol 145, 129-139.

Bradford, M. M. (1976). A rapid and sensitive method for the quantitation of microgram quantities of protein utilizing the principle of protein-dye binding. Anal Biochem 72, 248-254.

Chassy, B. M. \& Thompson, J. (1983). Regulation of phosphoenolpyruvate-dependent phosphotransferase system and $\beta$-Dphosphogalactoside galactohydrolase activities in Lactobacillus casei. J Bacteriol 154, 1195-1203.

Colwell, R. R., MacDonell, M. T. \& DeLey, J. (1986). Proposal to recognize the family Aeromonadaceae fam. nov. Int $J$ Syst Bacteriol 36, 473-477.

Conrad, R. \& Schlegel, H. G. (1977). Different degradation pathways for glucose and fructose in Rhodopseudomonas capsulata. Arch Microbiol 112, 39-48.

Crasnier, M. \& Danchin, A. (1990). Characterization of Escherichia coli adenylate cyclase mutants with modified regulation. J Gen Microbiol 136, 1825-1831.

Curtis, S. J. \& Epstein, W. (1975). Phosphorylation of D-glucose in Escherichia coli mutants defective in glucosephosphotransferase, mannosephosphotransferase and glucokinase. J Bacteriol 122, 1189-1199.

De Crécy-Lagard, V., Bouvet, O. M. M., Lejeune, P. \& Danchin, A. (1991a). Fructose catabolism in Xanthomonas campestris pv. campestris. J Biol Chem 266, 18154-18161.

De Crécy-Lagard, V., Bouvet, O. M. M., Lejeune, P. \& Danchin, A. (1991b). Identification of two fructose transport and phosphorylation pathways in Xanthomonas campestris pv. campestris. Mol Gen Genet 227, 465-472.

De Crécy-Lagard, V., Binet, M. \& Danchin, A. (1995). Fructose phosphotransferase system of Xanthomonas campestris pv. campestris: characterization of the fruB gene. Microbiology 141, 2253-2260.

Durham, D. R. \& Phibbs, P. V. J. (1982). Fractionation and characterization of the phosphoenolpyruvate:fructose 1-phos- photransferase system from Pseudomonas aeruginosa. J Bacteriol 149, 534-541.

Erni, B. \& Zanolari, B. (1985). The mannose-permease of the bacterial phosphotransferase system. Gene cloning and purification of the enzyme $\mathrm{II}^{\mathrm{Man}} / \mathrm{III}^{\mathrm{Man}}$ complex of Escherichia coli. J Biol Chem 260, 15495-15503.

Farmer, J. J., III (1992). The family Vibrionaceae. In The Prokaryotes, 2nd edn, pp. 2938-2951. Edited by A. Balows, H. G. Trüper, M. Dworkin, W. Harder \& K.-H. Schleifer. New York: Springer.

Farmer, J. J., III, Arduino, M. J. \& Hickman-Brenner, F. W. (1992). The genera Aeromonas and Plesiomonas. In The Prokaryotes, 2nd edn, pp. 3013-3045. Edited by A. Balows, H. G. Trüper, M. Dworkin, W. Harder \& K.-H. Schleifer. New York: Springer.

Ferenci, T. \& Kornberg, H. L. (1973). The utilization of fructose by Escherichia coli. Biochem J 132, 341-347.

Ferenci, T. \& Kornberg, H. L. (1974). Role of PTS mediated synthesis of fructose-1-P and fructose-6-P in the growth of Escherichia coli on fructose. Proc R Soc Lond Ser B 187, 105-119.

Feucht, B. U. \& Saier, M. H., Jr (1980). Fine control of adenylate cyclase by the phosphoenolpyruvate sugar phosphotransferase systems in Escherichia coli and Salmonella typhimurium. J Bacteriol 141, 603-610.

Geerse, R. H., Izzo, F. \& Postma, P. W. (1989). The PEP: fructose phosphotransferase system in Salmonella typhimurium: FPr combines Enzyme III $^{\text {rru }}$ and pseudo-HPr activities. Mol Gen Genet 216, 517-525.

Hanson, T. E. \& Anderson, R. L. (1968). Phosphoenolpyruvatedependent formation of $\mathrm{D}$-fructose-1-phosphate by a fourcomponent phosphotransferase system. Proc Natl Acad Sci USA 61, 269-276.

Jeanes, A., Pittsley, J. E. \& Senti, F. R. (1961). Polysaccharide B1459: a new hydrocolloid polyelectrolyte produced from glucose by bacterial fermentation. J Appl Polym Sci 5, 519-526.

Jones-Mortimer, M. C. \& Kornberg, H. L. (1974). Genetic analysis of fructose utilization by Escherichia coli. Proc R Soc Lond Ser B $187,121-131$.

Kubota, Y., luchi, S., Fujisawa, A. \& Tanaka, S. (1979). Separation of four components of the phosphoenolpyruvate:glucose phosphotransferase system in Vibrio parahaemolyticus. Microbiol Immunol 23, 131-146.

Leblanc, D. J., Crow, V. L., Lee, L. N. \& Garon, C. F. (1979). Influence of the lactose plasmid on the metabolism of galactose by Streptococcus lactis. J Bacteriol 137, 878-884.

Lessie, T. G. \& Neidhart, F. C. (1967). Adenosine triphosphatelinked control of Pseudomonas aeruginosa glucose-6-phosphate dehydrogenase. J Bacteriol 93, 1337-1345.

Lévy, S., Zeng, G. Q. \& Danchin, A. (1990). Cyclic AMP synthesis in Escherichia coli strains bearing known deletions in the $p t s$ phosphotransferase operon. Gene 86, 27-33.

Maniatis, T., Fritsch, E. F. \& Sambrook, J. (1982). Molecular Cloning: a Laboratory Manual. Cold Spring Harbor, NY: Cold Spring Harbor Laboratory.

Mattoo, R. L. \& Waygood, E. B. (1983). An enzymatic method for $\left[{ }^{32} \mathrm{P}\right]$ phosphoenolpyruvate synthesis. Anal Biochem 128, 245-249.

Meadow, N. D., Revuelta, R., Chen, V. N., Colwell, R. R. \& Roseman, S. (1987). Phosphoenolpyruvate:glucose phosphotransferase system in species of Vibrio, a widely distributed marine bacterial genus. J Bacteriol 169, 4893-4900.

Miller, J. H. (1972). Experiments in Molecular Genetics. Cold Spring Harbor, NY: Cold Spring Harbor Laboratory. 
Postma, P. W. \& Lengeler, J. W. (1985). Phosphoenolpyruvate: carbohydrate phosphotransferase system of bacteria. Microbiol Rev 49, 232-269.

Postma, P. W. \& Stock, J. B. (1980). Enzymes II of the phosphotransferase system do not catalyse sugar transport in the absence of phosphorylation. J Bacteriol 141, 476-484.

Postma, P. W., Lengeler, J. W. \& Jacobson, G. R. (1993). Phosphoenolpyruvate: carbohydrate phosphotransferase systems of bacteria. Microbiol Rev 57, 543-594.

Rephaeli, A. W. \& Saier, M. H., Jr (1980). Substrate specificity and kinetic characterization of sugar uptake and phosphorylation, catalyzed by the mannose enzyme II of the phosphotransferase system in Salmonella typhimurium. J Biol Chem 255, 8585-8591.

Saier, M. H., Jr, Feucht, B. U. \& Roseman, S. (1971). Phosphoenolpyruvate-dependent fructose phosphorylation in photosynthetic bacteria. J Biol Chem 246, 7819-7821.

Saier, M. H., Jr, Simoni, R. D. \& Roseman, S. (1976). Sugar transport. Properties of mutant bacteria defective in proteins of the phosphoenolpyruvate:sugar phosphotransferase system. $J$ Biol Chem 251, 6584-6597.

Scholte, B. J. \& Postma, P. W. (1981). Competition between two pathways for sugar uptake by the phosphoenolpyruvate-dependent sugar phosphotransferase system in Salmonella typhimurium. Eur J Biochem 114, 51-58.

Stolz, B., Huber, M., Markovic-Housley, Z. \& Erni, B. (1993). The mannose transporter of Escherichia coli. Structure and function of the IIAB ${ }^{\text {Man }}$ subunit. J Biol Chem 268, 27094-27099.

Tanaka, S., Lerner, S. A. \& Lin, E. (1967). Replacement of a phosphoenolpyruvate-dependent phosphotransferase by a nicotinamide adenine dinucleotide-linked dehydrogenase for the utilization of mannitol. J Bacteriol 93, 642-648.
Thornley, J. P., Shaw, J. G., Gryllos, I. A. \& Eley, A. (1997). Virulence properties of clinically significant Aeromonas species: evidence for pathogenicity. Rev Med Microbiol 8, 61-72.

Trotot, P., Sismeiro, O., Vivarès, C., Glaser, P., Bresson-Roy, A. \& Danchin, A. (1996). Comparative analysis of the cya locus in enterobacteria and related Gram-negative facultative anaerobes. Biochimie 78, 277-287.

Wawszkiewicz, E. J. (1961). A two dimensional system of paper chromatography of some sugar phosphates. Anal Chem 33, $252-254$.

Waygood, E. B., Mattoo, R. L. \& Peri, K. G. (1984). Phosphoproteins and the phosphoenolpyruvate: sugar phosphotransferase system in Salmonella typhimurium and Escherichia coli: evidence for II $^{\text {mannose }}$, III fructose, III $^{\text {glucitol }}$, and the phosphorylation of Enzyme $\mathrm{II}^{\text {mannitol }}$ and Enzyme II $^{N \cdot \text { acetylglucosamine }} . J$ Cell Biochem 25, 139-159.

Williams, N. D., Fox, K., Shea, C. \& Roseman, S. (1986). Pel, the protein that permits $\lambda$ DNA penetration of E. coli, is encoded by a gene in pts $\mathrm{M}$ and is required for mannose utilization by the phosphotransferase system. Proc Natl Acad Sci USA 83, 89348938.

Woese, C. R. (1987). Bacterial evolution. Microbiol Rev 51, 221-271.

Wu, L. F., Tomich, J. M. \& Saier, M. H., Jr (1990). Structure and evolution of a multidomain multiphosphoryl transfer protein. Nucleotide sequence of the $f r u B(H I)$ gene in Rhodobacter capsulatus and comparisons with homologous genes from other organisms. J Mol Biol 213, 687-703.

Received 7 August 1997; revised 23 October 1997; accepted 10 November 1997 